\title{
Colorimetric Determination of Benzocaine, Lignocaine and Procaine Hydrochlorides in Pure Form and in Pharmaceutical Formulations Using $p$-Benzoquinone
}

\author{
Alaa S. Amin* and Akram M. El-DiDAmonY**ं \\ * Chemistry Department, Faculty of Science, Benha University, Benha, Egypt \\ **Chemistry Department, Faculty of Science, Zagazig University, Zagazig, Egypt
}

\begin{abstract}
A simple, accurate and sensitive method for the microdetermination of benzocaine, lignocaine and procaine hydrochlorides in pure forms and in pharmaceutical formulations is described. The procedure is based on the reaction of those drugs in an aqueous acidic medium with $p$-benzoquinone to form charge-transfer complexes. The method has been used for the determination of 5.0-70,5.0-60 and 5.0-90 $\mathrm{gg} \mathrm{m}^{-1}$ of benzocaine, lignocaine $\mathrm{HCl}$ and procaine $\mathrm{HCl}$, respectively. The complexes have apparent molar absorptivities of $1.70 \times 10^{3}, 2.79 \times 10^{3}$ and $2.42 \times 10^{3} \mathrm{~L} \mathrm{~mol}^{-1} \mathrm{~cm}^{-1} \mathrm{and}$ Sandell sensitivities of 9.72, 10.34 and $11.25 \mathrm{ng} \mathrm{cm}^{-2}$, respectively. The proposed procedure of analysis is as accurate as the British Pharmacopoeial method (2003). The method was successfully used for the determination of those drugs in the presence of their degradation products, additives and excipients, which were normally encountered in pharmaceutical formulations.
\end{abstract}

(Received February 12, 2003; Accepted July 8, 2003)

Benzocaine [ethyl 4-aminobenzoate (94-09-7)], lignocaine hydrochloride [2-diethylaminoaceto-2,6-xylidide hydrochloride (6108-05-0)] and procaine hydrochloride [2-diethylaminoethyl4-aminobenzoate hydrochloride (51-05-8)] are widely used as local and epidural anesthesia in medical practice to relieve pain associated with ulcers.

Several methods have been reported for the determination of local anesthetics; these procedures involve potentiometric ${ }^{1,2}$ and coulometric titration $^{3}$ as well as an acid dye titrimetric technique. ${ }^{4}$ Different spectrophotometric procedures were described for the microdetermination of local anaesthetics under consideration. $^{5-10}$ Benzocaine was determined colorimetrically by diazotization and coupling with $m$-amino phenol ${ }^{11}$ or via the formation of a red Schiff base. ${ }^{12}$ Atomic absorption spectra ${ }^{13}$ and high-performance liquid chromatography ${ }^{14-20}$ were also used for their determination. Conductometric titration techniques ${ }^{21}$ using ammonium reineckate, potassium tetracyanonickelate and sodium cobaltinitrite were used for the determination of benzocaine, lignocaine and procaine hydrochlorides. Chargetransfer complexation reactions have been extensively used for the determination of electron-donating basic nitrogenous compounds using the acceptor iodine, polyhalo or polycyanoquinone as reagents in an organic solvent. ${ }^{22-25}$

In the present work, an attempt was made to provide a simple, accurate and sensitive method for the quantitative determination of benzocaine, lignocaine and procaine hydrochlorides as raw materials and in some pharmaceutical preparations without the interference of other constituent in the formulations.

\footnotetext{
$\doteqdot$ To whom correspondence should be addressed

E-mail: ameldidamony61@msn.com
}

\section{Experimental}

Ultraviolet and visible spectrophotometry were carried out on a Perkin Elmer $\lambda 3 \mathrm{~B}$ recording spectrophotometric equipped with $10 \mathrm{~mm}$ matched silica cells.

All chemicals and reagents used were of analytical or pharmaceutical grade. Benzocaine, lignocaine $\mathrm{HCl}$ and procaine $\mathrm{HCl}$ were obtained from Memphis Company, Egypt. Alcoholic solutions of $1 \times 10^{-3} \mathrm{M}$ of those drugs were prepared by dissolving an appropriate weight in the least amount of ethanol, and completing to $100 \mathrm{ml}$ in a measuring flask. Working solutions of lower concentrations were freshly prepared by appropriate dilution of a stock standard solution with ethanol.

A $5 \times 10^{-3} \mathrm{M}$ of $p$-benzoquinone was prepared by dissolving an accurate weight in a minimum amount of ethanol in a $100 \mathrm{ml}$ measuring flask, and completing to the mark with absolute ethanol.

\section{General procedure}

First, $1.0 \mathrm{ml}$ of a $5 \times 10^{-3} \mathrm{M} p$-benzoquinone solution was pipetted into a $10 \mathrm{ml}$ measuring flask. A volume containing up to 700,600 , or $900 \mu \mathrm{g}$ of benzocaine, lignocoine, or procaine, respectively, was added, followed by ethanol to achieve $30 \%$ (v/v). Then $5.0 \mathrm{ml}$ of $1.0 \mathrm{M} \mathrm{H}_{2} \mathrm{SO}_{4}$ was added and completed to the mark with water. The reaction mixture was left to stand at room temperature $\left(25 \pm 2^{\circ} \mathrm{C}\right)$ for 10,15 and $10 \mathrm{~min}$ for benzocaine, lignocaine and procaine, respectively. The absorbance was measured at $525 \mathrm{~nm}$ against a reagent-blank solution prepared simultaneously.

A $5.0 \mathrm{ml}$ aliquot on vial or one gram of ointment was transferred into a separating funnel, rendered alkaline with sufficient quantity of sodium hydroxide, and extracted with 


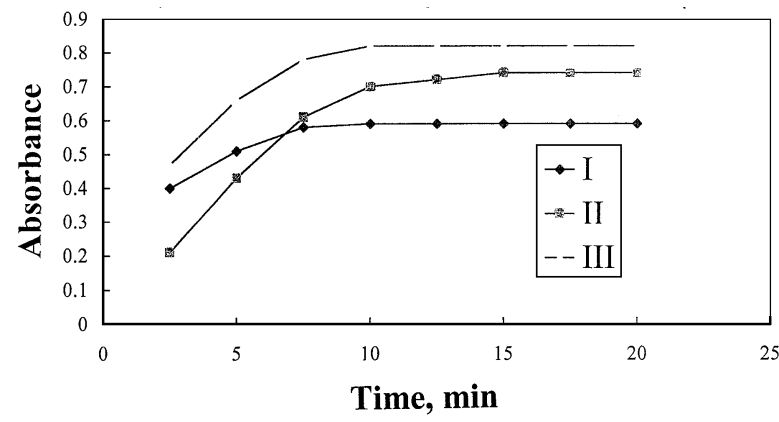

Fig. 1 Effect of time on the absorbance of $40 \mu \mathrm{g} \mathrm{ml}{ }^{-1}$ of I, benzocaine; II, lignocaine; and III, procaine.

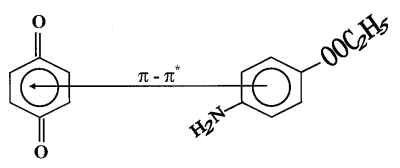

Scheme 1

different portions of a total of $60 \mathrm{ml}$ of chloroform $(15 \mathrm{ml} \times 4)$. The chloroform layer was evaporated to dryness, and an appropriate weight equivalent to $60 \mathrm{mg}$ of drug was dissolved in $100 \mathrm{ml}$ of ethanol. The general procedure was then followed on the concentration ranges mentioned above.

\section{Results and Discussion}

$p$-Benzoquinone has been previously used for the determination of total proteins in skim milk, ${ }^{26}$ rate tissues ${ }^{27}$ and in mixtures. ${ }^{28}$ Under the reaction conditions used, which included heating at $100^{\circ} \mathrm{C}$, it was observed that the products of the reaction between $p$-benzoquinone and proteins absorbed at $\simeq 350 \mathrm{~nm}$ for amino acids. The products of the reaction absorbed in the range of 390 $-670 \mathrm{~nm}$, but most of them absorbed at about $430-440 \mathrm{~nm}$.

Because benzocaine, lignocaine $\mathrm{HCl}$ and procaine $\mathrm{HCl}$ contain primary and secondary amino groups, attempts were made to use $p$-benzoquinone ( $\pi$-acceptor) for determining the aforementioned compounds. The small molar absorptivity may due to insufficient ionization of $p$-benzoquinone (weak $\pi$ acceptors), which possesses a low electron affinity. The redcolored products can be described as charge-transfer complex formation that takes place through a $\pi$ - $\pi^{*}$ transition from the studied drugs to $p$-benzoquinone. The colored reaction product can be represented, taking benzocaine as an example (shown in Scheme 1).

In this work, colorimetric determinations of the complexation reactions of three local anesthetics containing primary and secondary aromatic amino groups, were applied. The influence of various reaction variables on the color development was tested to establish the most favorable conditions.

Different acids were tested to choose the optimal media for complete complex formation. Sulfuric acid with $1.0 \mathrm{M}$ concentration was found to be the best one. Complete color development was obtained upon using $5.0 \mathrm{ml}$ of a $1.0 \mathrm{M} \mathrm{H}_{2} \mathrm{SO}_{4}$ in $10 \mathrm{ml}$ measuring flask.

When various concentrations of $p$-benzoquinone solution were added to a fixed concentration of drug $\left(40 \mu \mathrm{g} \mathrm{ml}^{-1}\right), 0.8 \mathrm{ml}$ of $5 \times 10^{-3} \mathrm{M}$ was sufficient to develop the color to its full intensity. To ensure complete color development, an excess
Table 1 Quantitative parameters for the complexation of benzocaine, lignocaine $\mathrm{HCl}$ and procaine $\mathrm{HCl}$ with $p$ benzoquinone

\begin{tabular}{|c|c|c|c|}
\hline Parameters & Benzocaine & Lignocaine & Procaine \\
\hline $\begin{array}{l}\text { Beer's law limits, } \\
\mu \mathrm{g} \mathrm{m}^{-1}\end{array}$ & $5.0-70$ & $5.0-60$ & $5.0-90$ \\
\hline $\begin{array}{l}\text { Molar absorptivity, } \\
\mathrm{L} \mathrm{mol}^{-1} \mathrm{~cm}^{-1}\end{array}$ & $1.7 \times 10^{3}$ & $2.79 \times 10^{3}$ & $2.42 \times 10^{3}$ \\
\hline $\begin{array}{l}\text { Sandell sensitivity, } \\
\mathrm{ng} \mathrm{cm}^{-2}\end{array}$ & 9.72 & 10.34 & 11.25 \\
\hline $\begin{array}{l}\text { Ringbom optimum } \\
\text { range, } \mu \mathrm{g} \mathrm{ml}^{-1}\end{array}$ & $10-60$ & $10-55$ & $10-75$ \\
\hline Range of error, (\%) & \pm 1.5 & \pm 1.2 & \pm 1.7 \\
\hline Standard deviation, $(\%)$ & 0.83 & 0.69 & 0.98 \\
\hline \multicolumn{4}{|l|}{ Regression equation $^{\mathrm{a}}$} \\
\hline Slope & 0.0148 & 0.0185 & 0.0205 \\
\hline Intercept & -0.017 & +0.025 & +0.009 \\
\hline Correlation coefficient & 0.9996 & 0.9988 & 0.9985 \\
\hline
\end{tabular}

a. $A=a+b C$, where $C$ is the concentration in $\mu \mathrm{g} \mathrm{ml}^{-1}$.

$(1.0 \mathrm{ml})$ of $p$-benzoquinone was used for all experiments within the concentration ranges given in Table 1 .

The maximum color intensity of the reaction mixture was attained after 10, 15 and 10 min for benzocaine, lignocaine and procaine respectively, at $25 \pm 2^{\circ} \mathrm{C}$ as shown in Fig. 1. Raising the temperature of the reaction mixture up to $60^{\circ} \mathrm{C}$, on a water bath had no effect. The color of the final solution was stable for 6.0, 4.0 and $6.0 \mathrm{~h}$ for benzocaine, lignocaine $\mathrm{HCl}$ and procaine $\mathrm{HCl}$ complexes, respectively.

The solvents used in the studies were methanol, ethanol, propan-1-ol, acetone, dioxane, hexanol and dimethylformamide. Ethanol as a universal solvent gave the maximum color intensity; $30 \%(\mathrm{v} / \mathrm{v})$ was found to be the optimum ratio for the highest absorbance values. The absorption spectra of the reaction products under these conditions showed a high absorption band at $525 \mathrm{~nm}$.

The stoichiometry of the formed charge-transfer complex between each drug with $p$-benzoquinone was investigated under the recommended optimum conditions by applying the molar ratio and continuous variation methods. The results indicated that all drugs form a 1:1 charge-transfer complex.

\section{Quantification}

Typical calibration data for the three local anesthetics investigated, obtained from a linear regression analysis of the absorbance readings vs. concentration of each drug $\left(\mu \mathrm{g} \mathrm{ml}^{-1}\right)$, gave the slope, intercept, and correlation coefficients (Table 1). The linear correlation graphs obtained for investigated anesthetics can also be used to calculate the concentrations of the drugs. Moreover, a Ringbom optimum concentration range could be calculated which gave more accurate results. The apparent molar absorptivities $(\varepsilon)$ of the resulting charge-transfer complexes were $1.70 \times 10^{3}, 2.79 \times 10^{3}$ and $2.42 \times 10^{3} \mathrm{~L} \mathrm{~mol}^{-1}$ $\mathrm{cm}^{-1}$ for benzocaine, lignocaine $\mathrm{HCl}$ and procaine $\mathrm{HCl}$, respectively, whereas the Sandell sensitivities were 9.72, 10.34 and $11.25 \mathrm{ng} \mathrm{cm}^{-2}$, respectively.

To examine the accuracy and precision of the procedure, eight replicate determinations were made on the same solution containing $40 \mu \mathrm{g} \mathrm{ml}^{-1}$ of each of the investigated anesthetics. The following coefficients of variation $(\mathrm{CV})$ were obtained: $0.83,0.69$ and $0.98 \%$ for benzocaine, lignocaine $\mathrm{HCl}$ and procaine $\mathrm{HCl}$, respectively.

Statistical analyses of the results using the Student t-test and 
Table 2 Assay of anesthetics drugs in bulk and in some pharmaceutical formulations by the proposed and official methods

\begin{tabular}{|c|c|c|c|c|}
\hline \multirow[b]{2}{*}{ Sample } & \multirow{2}{*}{$\begin{array}{l}\text { Taken/ } \\
\mu \mathrm{g} \mathrm{ml}^{-1}\end{array}$} & \multirow{2}{*}{$\begin{array}{l}\text { Added/ } \\
\mu \mathrm{g} \mathrm{ml}^{-1}\end{array}$} & \multicolumn{2}{|c|}{ Found $/ \mu \mathrm{g} \mathrm{ml}^{-1}(n=6)$} \\
\hline & & & $\begin{array}{c}\text { Proposed } \\
\pm \text { S.D } \%\end{array}$ & $\begin{array}{l}\text { Official } \\
\pm \text { S.D } \%\end{array}$ \\
\hline \multirow{4}{*}{$\begin{array}{l}\text { Benzocaine } \\
\text { pure }\end{array}$} & \multirow[t]{4}{*}{20} & - & $20.1 \pm 0.53$ & $20.3 \pm 1.12$ \\
\hline & & 15 & $34.8 \pm 0.71$ & $35.5 \pm 1.37$ \\
\hline & & 30 & $50.3 \pm 0.39$ & $49.3 \pm 1.22$ \\
\hline & & 45 & $65.4 \pm 0.66$ & $66.0 \pm 0.96$ \\
\hline \multirow{3}{*}{$\begin{array}{l}\text { Dentocalm } \\
\text { ointment }^{\mathrm{a}}\end{array}$} & \multirow[t]{3}{*}{30} & - & $30.1 \pm 0.42$ & $30.3 \pm 0.99$ \\
\hline & & 10 & $40.2 \pm 0.67$ & $40.5 \pm 0.86$ \\
\hline & & 20 & $50.3 \pm 0.83$ & $49.6 \pm 0.83$ \\
\hline \multirow{4}{*}{$\begin{array}{l}\text { Lignocaine } \\
\mathrm{HCl} \text { pure }\end{array}$} & \multirow[t]{4}{*}{15} & - & $14.9 \pm 0.98$ & $15.2 \pm 0.89$ \\
\hline & & 15 & $30.1 \pm 0.79$ & $29.7 \pm 1.13$ \\
\hline & & 30 & $45.3 \pm 0.38$ & $44.5 \pm 1.22$ \\
\hline & & 45 & $59.5 \pm 0.61$ & $60.8 \pm 1.37$ \\
\hline \multirow{4}{*}{$\begin{array}{l}\text { Xylocaine } \\
\text { vail }^{\mathrm{b}}\end{array}$} & \multirow[t]{4}{*}{30} & - & $29.8 \pm 0.37$ & $29.6 \pm 1.11$ \\
\hline & & 10 & $40.1 \pm 0.44$ & $39.8 \pm 0.83$ \\
\hline & & 20 & $50.3 \pm 0.69$ & $50.6 \pm 1.09$ \\
\hline & & 30 & $59.4 \pm 0.77$ & $60.8 \pm 1.16$ \\
\hline Procaine & \multirow[t]{4}{*}{40} & - & $39.6 \pm 0.93$ & $39.5 \pm 0.96$ \\
\hline \multirow[t]{3}{*}{$\mathrm{HCl}$ pure } & & 15 & $44.8 \pm 0.69$ & $45.6 \pm 1.18$ \\
\hline & & 30 & $70.4 \pm 0.51$ & $69.5 \pm 0.83$ \\
\hline & & 45 & $85.6 \pm 0.75$ & $84.0 \pm 1.27$ \\
\hline
\end{tabular}

a. Dentocalm (Pharco. Pharm. Alex. Egypt) each gram contain 60 $\mathrm{mg}$ of benzocaine and $100 \mathrm{mg}$ clove oil.

b. Xylocaine (Egypt Company for Pharmaceutical \& Chemical Industry).

variance-ratio (F-value), showed that both values did not exceed the theoretical values. This demonstrated that there is no significant different between the official method ${ }^{29}$ (based on the addition of excess $\mathrm{KBr}$ and then titration with $\mathrm{NaNO}_{2}$ ) and the proposed method.

The proposed procedure was applied to a determination of the studied drugs in some pharmaceutical formulations by applying the standard addition technique. The obtained results (Table 2) were compared with those of the official method. ${ }^{29}$

The proposed procedure has the advantages of analyzing drugs in their pharmaceutical dosage forms without interference from additives or excipients due to the involvement of a selective solvent extraction, as in the case of xylocaine and dentocalm. Chloroform is used to extract the active ingredients without excipients or additives. The procedure retained its accuracy and precision as the official method in addition to simplicity of the reagent and apparatus and the wide range of determination.

\section{References}

1. S. M. Ionescu and V. V. Cosofret, Analyst, 1985, 110, 922.
2. G. Tortolani, Farmaco Ed., Prat., 1974, 29, 272.

3. S. Kosasih, S. Tisno, and T. Hermini, Acta Pharm. Indones, $\mathbf{1 9 8 5}, 10,37$.

4. F. M. EL-Tarras and M. Zeinab, Chem. Biomed. Environ. Instrum., 1981, 11, 411.

5. L. Zivanovic, S. Agatonovic, M. Vasiljevic, L. Markovic, and I. Nemeova, Pharmazie, 1994, 49, 927.

6. A. Gruz, M. Lopez-Rivadulla, A. M. Bermejo, I. Sanchez, and P. Fernandez, Anal. Lett., 1994, 27, 2663.

7. A. V. Pavlova, G. I. Ljutakov, and A. N. Zlatinova, Anal. Lab., 1995, 4, 42.

8. N. Erk and F. Onur, Pharma. Sci., 1996, 6, 216.

9. F. A. Mohamed, A.-M. I. Mohamed, H. A. Mohamed, and S. A. Hussein, Talanta, 1996, 43, 1931.

10. N. S. Jr. Viana and C. D. Vianna-Sqares, Rev. Bras. Cienc. Farm., 1999, 35, 133.

11. S. Tan Henry, A. Gary, and S. David, J. Pharm. Sci., 1977, 66, 1037.

12. A. F. Minka, I. I. Kopuchuk, V. I. Shkadova, and V. P. Kalashnikov, Pharm. Zh. [Kiev], 1984, 2, 37.

13. M. A. El-Ries, F. M. Abou Attia, F. M. Abdel-Gawad, and S. M. Abu El-Wafa, J. Pharm. Biomed. Anal., 1994, 12, 1209.

14. X. Y. Wang, Fenxi Huaxue, 1994, 22, 644.

15. I. Caraballo, M. Fernandez Arevalo, M.-A. Holgado, M.-T. Vela, and A.-M. Rabasco, J. Pharm. Sci., 1994, 83, 1147.

16. F. Ortiz-Boyer, M. T. Tena, M. D. Luque de Castro, and M. Valcarcel, J. Pharm. Biomed. Anal., 1995, 13, 1297.

17. S. Liawruangrath and B. Liawruangrath, J. Pharm. Biomed. Anal., 1999, 20, 401.

18. M. Parissi-Poulou and I. Panderi, J. Liq. Chromatogr. Relat. Technol., 1999, 22, 1055.

19. A. S. Amin and I. S. Ahmed, Mikrochim. Acta, 2001, 137, 35 .

20. A. S. Amin and A. M. El-Beshbeshi, Mikrochim. Acta, 2001, 137, 63 .

21. A. S. Amin and Y. M. Issa, Chin. Pharm. J, 1995, 47, 147.

22. M. M. Ayad, S. Belal, S. M. El-Adl, and A. Abuo AlKheir, Analyst, 1984, 109, 1417.

23. M. Rizk and F. Younis, Anal. Lett., 1984, 17, 1803.

24. U. Muralikrishna, M. Krishnamurthy, and N. Somewara, Analyst, 1984, 109, 1277.

25. E. Ibrahim, A. S. Issa, M. A. Abdel-Salam, and M. S. Mohrous, Talanta, 1983, 30, 531.

26. W. J. Barreto, M. De Aquino, and D. A. M. Zaia, Anal. Lett., 1990, 23, 1279.

27. D. A. M. Zaia, S. R. Rockenbach, M. M. Obara, W. J. Barreto, S. Arizawa, R. Curi, and J. Lichtig, Anal. Lett., 1992, 25, 1225.

28. D. A. M. Zaia, W. J. Barreto, N. J. Santos, and A. S. Endo, Anal. Chim. Acta, 1993, 277, 89.

29. British Pharmacopoeia, Her Majesty's Stationary Office, 2003, London, 7, 94, and 558. 